DOI: $10.20472 / E S .2019 .8 .2 .004$

\title{
DEVELOPMENT OF REAL UNIT WAGE COSTS ON THE MACRO- AND MEZO-LEVEL OF THE CZECH REPUBLIC
}

\author{
BOZENA KADERABKOVA, EMILIE JASOVA
}

\begin{abstract}
:
The aim of the paper is to analyse the development and the level of cost inflation pressures originating from the labour market in terms of the different levels of the Czech Republic. At first, we will mention several definitions of unit labour costs and the reasons for their examination and monitoring. Then we will select the concept of the nominal and real unit wage costs and data for the macro-level and mezzo-level in the Czech Republic. It is also evaluated the development of real unit wage costs indicator on individual levels of the Czech Republic and extent the wage inflation potential on them. Finally, we localize the first clues about the negative impact of wages on prices on the mezzo-level, which can be used for creating the prediction of the national economy in the near future.
\end{abstract}

\section{Keywords:}

Wage cost inflation pressures, nominal unit wage costs, real unit wage costs, mezzo-level, macro-level, wage cost inflation potential

JEL Classification: E24, E32, E37

\section{Authors:}

BOZENA KADERABKOVA, Faculty of Civil Engineering, Czech Technical University in Prague, Czech Republic, Email: Kaderabb@fsv.cvut.cz

EMILIE JASOVA, Ministry of Labour and Social Affairs, Czech Republic, Email:

ekonomka_2@hotmail.com

\section{Citation:}

BOZENA KADERABKOVA, EMILIE JASOVA (2019). DEVELOPMENT OF REAL UNIT WAGE COSTS ON THE MACRO- AND MEZO-LEVEL OF THE CZECH REPUBLIC. International Journal of Economic Sciences, Vol. VIII(2), pp. 45-59., 10.20472/ES.2019.8.2.004 


\section{Introduction}

The European Commission (2012) considers as the reason for the economic crisis macroeconomic imbalance. It manifests in the form of high and long-term external deficits, a permanent loss of competitiveness, and indebtedness. The imbalance leads to macroeconomic problems which spread across other areas, thus becoming ever more profound. According to Raputa (28/01/2013), the increase in salaries, contradictory to the productivity development, leads to weakening the exchange rate. The author perceives the exchange rate channel as much more flexible than the salaries and productivity, because the growth in the competitiveness appears within several months.

Prušvic, and Vlach (2006) state that the indicator the unit labour costs (hereinafter only as the "ULC") represents a composite expression of the workforce pressures in the economy. The central banks use this indicator to forecast the inflation rate (inflation cost factor) and to assess the level of competitiveness in the economy. Lipská, Vlnková, and Macková (2005) considered the indicator of unit labour costs as senior supplemental indicator, which is used in evaluation of the economic development.

Vlach, and Kozelský (2010) perceive the labour costs as the basis of national production and total reproduction costs. These costs determine the competitive position on world markets. The volume of labour costs, labour prices, and productivity determine the investors' activity in the region. The authors compare the labour costs with the productivity and the results provide them with a view of the cost and competitive position of individual companies and national economies on the single internal EU market and world markets. In particular, the authors use the term of unit labour costs.

The Czech National Bank (Leden 2001b) assesses the effect of wage development on inflation by a double effect of wage on the inflation development. This institution perceives salaries as a potential source of cost- and demand inflationary pressures. The imbalance on the labour market in the form of inflation is implied in the indicator of nominal unit wage costs (hereinafter only as the "NUWC") or real unit wage costs (hereinafter only as the "RUWC").

According to Raputa (14/10/2013), it is the RUWC that functions as a indicator assessing the economy's competitiveness. The author compares the actual value of the RUWC index with its long-term development for thirty countries. In the case that the RUWC index is above the longterm trend and the country has a significant deficit on the current account, the local currency is overvalued. Reducing the RUWC will increase the competitiveness of exports and establish the balance on the current account.

In the first section, the analysis will outline the definitions of unit labour costs. The second part selects the measurement methods of NUWC, respectively RUWC and dates for the chosen level of Czech Republic. The third part analyzes the development of RUWC in the Czech Republic. Apart from a macroeconomic perspective, attention will be paid to the mezzo-level (sectors and regions). The fourth section will assess the extent of the inflation potential of the Czech Republic in the labor market from different perspectives. The fifth part maps the first signs of the negative impact of wages on prices on the mezzo-level, which are used to create the prediction of the national economy in the near future. The last part submits conclusions.

\section{Unit labour/wage costs according to various definitions}

Vlach et al. (2013) maintain that there are different methodologies for monitoring labour costs in the Czech Republic and abroad owing to the data availability and the examination purpose. Apart 
from complex calculations, foreign and domestic institutions apply a number of simple conjunctural indicators. A disadvantage to this includes difficulties in international comparison. The authors have come up with the Certified Methodology based on individual methods for assessing the data sources in four problematic areas (monitoring the labour costs, calculating the labour share in the costs, calculating the ULC, and the analysis of the ULC development).

The author's algorithm of the calculation of the level indicator of the real unit labour costs (hereinafter only as the "RULC") is described as the share of the average labour costs expressed in compensation per employee and the GDP per employee in current prices in the national and European price level. In the case of the indicator defined in relation to the sectors, the labour productivity is calculated using the added value. On the corporate level, the productivity is expressed in relation to employees. The calculations are made on the basis of the level indicator which describes the proportion in using the labour in the Czech economy and the changes in relation to the convergence of the price level.

The ULC in the national price level are defined as follows:

$$
U L C n p=\frac{\frac{N E C}{\text { employees }}}{\frac{\text { GDPYnp }}{\text { employment }}},
$$

Where "ULCnp" means the ULC in the national price level, "NEC" is the nominal volume of employee compensation in the given period and in the currency $Y$ taken from national accounts, "employees" is an average number of employees in the given period and taken from the national accounts, "GDPYnp" is the GDP or the gross added value in the currency $Y$ in the national price level (in current prices and taken from the national accounts), and "employment" is the average number of total employment in the given period taken from the national accounts in the national concept.

According to Prušvic, and Vlach (2006), the ULC term represents a share of the performed work per production unit. For the purposes of a more accurate expression, the authors convert the data into a common unit. On the level of the national economy, the ULC may be calculated as a share of unit employee compensation in the general labour productivity. The indicator then shows the amount of mandatory costs of employees associated with the unit of the created product. It thus shows the volume of funds spent per employee and how much the employee produces as a result of their work.

Raputa (28/01/2013) deals with the ULC within the fundamental analysis. The comparison of this indicator between the countries determines the deviations of the values from the balanced trend, to be subsequently perceived as an expression of its overvaluation or undervaluation. The ULC gives author an answer to the question of how much has changed the price of labor, which is in relation to the previous period required to produce a unit of real output. The indicator thus shows the level of competitiveness of the given country in international trade. The low ULC allow exporters to sell their goods less expensively abroad, thus maintaining their competitive advantage.

The ULC are defined as follows:

$$
\Delta \text { Index }=\frac{\Delta \text { salaries }}{\Delta \text { productivity }} * \Delta \text { exchange_rate, }
$$


Where " $\Delta$ salaries" means y-to-y increase in salaries, " $\Delta$ productivity" means y-to-y increase in labour productivity, and " $\Delta$ exchange_rate" means y-to-y change in the exchange rate.

The publications of the Inflation Report (Czech National Bank from October 1998 to October 2001) show that the basic way of evaluating potential wage-cost inflationary pressures in the economy are indicators of NUWC and RUWC. Situation Report on Economic and Monetary Developments published on the website of the Czech National Bank with the delay (Czech National Bank from February 1999 to April 2000b) further analysis of this area specify. Most attention, however, CNB devoted to this issue in a methodical box (Czech National Bank January 2001b). Here it is stated that salaries may fulfil at the same time function both as a potential cost and demand inflation factor, and this distinction is not straightforward. According to the CNB, we may speak of wage-cost inflation in terms of excessive demand in the case when there is a faster growth of salaries compared to the product growth due to the development of the overall demand hitting the supply limits in the economy. In this situation, the lack of balance transfers from the goods market to the labour market, which leads to the decline in unemployment and at the same time, to the increase in average nominal salary rates. An increase in additional costs eventually leads to an increase in consumer prices, and an increase in prices thus passes from the cost side of producers to sellers. Both sides may temporarily absorb and alleviate higher prices adapting the commercial range. In the longer-term, however, they either abandon the market or shift the price pressure into end-consumer prices. The vigour of price increase depends on the competitive environment in the retail market segment, on the price elasticity of demand, on the size and duration of the imbalanced salary pressure, and on the non-demand cost factors (e.g. foreign prices and exchange rates). According to the CNB, we may speak of the autonomous cost inflation when an excessive increase in salaries (compared to the increase in the product) is due to partial disturbances in the relation of the salary and the product (e.g. technical accidents, an increase in salaries not corresponding to the demand development, or overvalued inflation expectations).

For the purposes of identifying imbalance on the labour market (whether the salary development corresponds to the development in the added value), the CNB uses the NUWC and RUWC as the inflation factor.

The NUWC may be calculated as follows:

$$
\Delta N U W C=\frac{\Delta \text { no min } a l_{-} \text {salaries }}{\Delta G D P_{-} c . p .},
$$

Where the " $\triangle$ NUWC" means an y-to-y change in the NUWC, " $\Delta$ nominal_salaries" is an y-to-y change in the volume of nominal salaries, and " $\Delta$ GDP_c.p." is $y$-to-y change of the gross domestic product in constant prices. The table in section III. 4 Labour Market (Chapter III. The current economic growth) and especially Tables and graphs in format Excel (Czech National Bank 2014) show that NUWC are calculated by a year to year changes in the indicators used (nominal salaries and GDP in c.p.).

The RUWC is calculated as follows:

$$
\Delta R U W C=\frac{\Delta N U W C}{\Delta d e f l_{-} G D P},
$$


Where " $\triangle R U W C$ " is $y$-to-y change in the RUWC, " $\triangle N U W C$ " is $y$-to-y annual change in the NUWC, and " $\Delta$ defl._GDP" is y-to-y change of the GDP deflator. The table in section III. 3.2 Wages and incomes - Chapter III. 3 Labour Market (Czech National Bank 2001b) reveals that RUWC is calculated from y-to-y changes both the default indicators (GDP deflator and NUWC).

In the methodology section, the CNB also states that the type of inflation pressures, originating from the NUWC increase (i.e. cost, demand or mutual pressure), imply the reasons for changes in their dynamics.

In this case the NUWC indicator is calculated as follows:

$$
\Delta N U W C=\frac{\Delta n o m ._{-} \text {salary }}{\Delta \text { real._productivity }},
$$

Where " $\triangle$ NUWC" is y-to-y change in the NUWC, " $\Delta$ nom._salary" is y-to-y change in the nominal salary, and " $\Delta$ real._productivity" is y-to-y change in the real labour productivity.

\section{Measurement of NUWC respectively RUWC and dates for the selected levels of the Czech Republic}

In this part we choose from the methodology of major international and domestic institutions in the previous chapter a way of measuring wage cost inflation and potential wage cost inflationary pressures. NUWC and RUWC we will express along the lines of e.g. the European Central Bank, Eurostat, DG ECFIN5, and the Czech National Bank in form of indexes, i.e. in the form of growth or decline rates or stagnation, rather than absolute values.

The specific identification of the imbalance on the labour market as an inflation factor originating from the wage development not corresponding to the added value development will be performed using the Czech National Bank indicators (Equation (3) and (4) in the previous chapter). The difference will be that for the purposes of calculating the NUWC and RUWC on the national economy level, we will prefer the added value index in 2010 prices taken from the national accounts of the Czech Statistical Office (quarterly accounts) to the GDP index in constant prices.

On the macroeconomic level, the NUWC will thus be calculated as follows:

$$
\triangle N U W C=\frac{\Delta \text { wages_salaries }}{\Delta G A V},
$$

Where " $\triangle$ NUWC" is y-to-y change in the NUWC (\%), " $\Delta$ wages_salaries" is y-to-y change in wages and salaries in current prices according to the quarterly CSO national accounts (\%), and " $\triangle \mathrm{GAV}$ " is y-to-y change of the gross added value taken from the quarterly CSO national accounts in 2010 prices (\%).

The RUWC calculation will use the CNB algorithm, in which we will nevertheless replace the GDP deflator with the gross added value deflator. Therefore, the following equation applies:

$$
\triangle R U W C=\frac{\Delta N U W C}{\Delta d e f l . \_G A V},
$$

Where " $\triangle$ RUWC" is y-to-y change in the RUWC (\%), " $\triangle$ NUWC" is y-to-y change in the NUWC $(\%)$, and " $\Delta$ defl._GAV" is y-to-y gross added value deflator in 2010 prices taken from CSO national accounts (\%). 
The adapted calculation, including the identical indicators and data sources, will also be used in the case of calculating the NUWC and RUWC in individual sectors. In particular, we will describe the imbalances on the labour market as an inflation factor in the sector of Agriculture, forestry and fishing (hereinafter only as the "Agriculture"), Manufacturing, mining and quarrying and other industry (hereinafter only as the "Industry"), Construction, Trade, transportation, accommodation and food service (hereinafter only as the "Trade"), Information and communication (hereinafter only as the "Information"), Financial and insurance activities (hereinafter only as the "Financial activities"), Real estate activities (hereinafter only as the "Real estate"), Professional, scientific, technical and administrative activities (hereinafter only as the "Professional activities"), Public administration, education, health and social work (hereinafter only as the "Public administration") and Other service activities (hereinafter only as the "Other activities").

The development of the NUWC and RUWC indicators will also be evaluated on the level of individual regions. When calculating the gross added value in 2010 prices first we take from the CSO regional accounts (indicators in the regional classification) the GDP data in current prices and previous period prices (in millions CZK) for individual regions. Dividing the GDP in both expressions we will provide the deflator of the gross domestic product (previous year's prices) for individual regions, which be subsequently transferred to year 2010. Furthermore, the CSO regional accounts (indicators in the regional classification) will be used for their gross added value in current prices for individual regions (in millions CZK), which will be divided by the GDP deflator in 2010 prices for individual regions. The resulting gross added value in 2010 prices for individual regions will be recalculated in the annual changes (\%). In addition, the CSO regional accounts (indicators in the regional classification) may also be used to obtain the value of employee compensation in current prices (in millions CZK). By means of an expert estimate of the Czech Statistical Office, this was used to obtain the values of wages and salaries in individual regions. The NUWC in the Capital City of Prague, Central Bohemian Region, South Bohemian Region, Plzeň Region, Karlovy Vary Region, Ústí nad Labem Region, Liberec Region, Hradec Králové Region, Pardubice Region, Vysočina Region, South Moravian Region, Olomouc Region, Zlín Region, and Moravian-Silesian Region will be calculated using pattern (6). The RUWC calculation will be made using the original CNB algorithm according to equation (4).

\section{Development of real unit wage costs at selected levels of the Czech economy}

The starting point for the analysis is examining the creation of a wage-inflationary potential in the form RUWC that comes from comparison of the NUWC with the development of the deflator of gross value added (in the case of regions with a GDP deflator for each region).

Figure 1 Development of real unit wage costs in the National economy, Industry, and Central Bohemian Region 


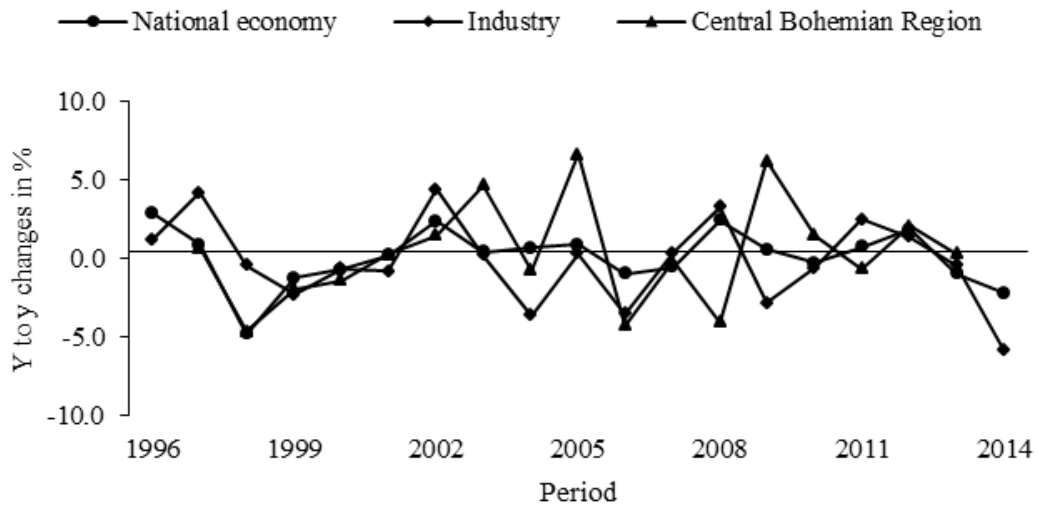

Source: Own calculation on the basis of data from the Czech Statistical Office.

In the whole national economy in 1996, the RUWC saw an annual increase (of $2.9 \%$ ), which indicated that the overall volume of incurred cost-related inflation pressures arising from the labour market had not been absorbed in the current price level and there had been a reservoir with a risk of being released in the following period rich in demand. This applies to the effect in the sectors of Agriculture, Trade, Financial activities, Real estate, and Other activities.

The analysis of the development of the effect of the labour market on cost-related inflation in the Czech Republic in 2008 and 2009 implies a negative conclusion also, as the RUWC saw an annual growth of $1.5 \%$. The deflator of the gross added value failed to absorb the whole volume of inflation pressures arising from the labour market, and a part of them was accumulated, thus becoming a risk for accelerating inflation in the future. The result of the evaluation is adequate for nearly all the sectors. The exception to the previous conclusions includes the sector of Financial activities, where all the current cost-related inflation pressures were absorbed in the ordinary price level. It was a rational attempt to link wage costs with added value. The same follows from the analysis of the Ústí nad Labem and Olomouc Regions.

Between 2011 and 2012 the average annual growth RUWC of 1.3\% was the result of developments in practically all sectors. Development of nominal and real wages in these sectors was not accompanied by the necessary growth of real variables, especially labor productivity growth. Identical trend was confirmed in most regions. The evaluation provides a signal concerning the accumulation of current inflation pressure arising from the labour market and the redistribution of the created product to the detriment of profits. Contrary to this general conclusion, there is the development in the Agriculture sector, which is characterized by intention to keep the wage-cost inflationary pressures at an acceptable level. Vysočina Region became a single region not suffering from regional imbalance on the labour market and which did not produce any risks of inflation pressures for the future development of the real economy.

In 1998 to 2000, there was conversely a decline in the RUWC (on average, by $2.2 \%$ ), and the development of the wage intensity of production did not create conditions for the occurrence of the wage-related inflation potential. The identical development was identified in most sectors, in which this year has not been allowed to grow wage intensity per unit of added value. The highest decline in the RUWC was found in Pardubice, Central Bohemian, and Vysočina Regions. The exception included the sectors of Agriculture, Industry, Trade, Financial activities, and Real estate, where the current cost-related inflation pressure had not been absorbed in the prices of the current period and they were being accumulated for the future. 
In 2010, the RUWC indicator declined annually by $0.2 \%$, thus receives a positive evaluation in the analysis. A lower annual decline in deflator compared to the RUWC decline thus implied the absorption of the wage and cost-related inflation pressures in the inflation of this period, as well as the non-existence of the risk of accelerating the price level in the immediately following period, e.g. alongside an increase in consumer demand or economic recovery. The identical conclusion also applies to the development in the sector of Agriculture, Industry, Public administration, Trade, and Financial activities. The development of labour market costs pointed to stop cumulation of wage inflation and a weakening of the potential disequilibrium of wage and production quantities. The same tendency was also found in most regions. The annual decline in the national economic RUWC was not supported by the development in four sectors (Information, Real estate, Professional activities, and Other activities). Furthermore, there were 5 regions (the Capital City of Prague, Central Bohemian Region, South Bohemian Region, Vysočina Region, and Olomouc Region). The RUWC in this group signalled the risk of releasing the accumulated cost-related inflation pressures arising from the labour market in the future inflation.

In 2013, the RUWC index declined annually by $0.9 \%$, and exceeding the annual growth of the gross added deflator above the level of the NUWC growth implied the absorption of wage and cost-related inflation pressures into the inflation of this period, as well as the non-existence of risk for accelerating the price level in the immediately following period, e.g. alongside an increase in consumer demand or economic recovery. The established tendency corresponds to the development in most sectors. The decrease in labor costs per unit of value added increased profit for firms or reduced other rising costs. It was also supported by Plzeň, Karlovy Vary and Hradec Králové Regions. The decline in the average RUWC of the national economy was not reflected in the sectors of Agriculture, Information, Real estate, and in Public Administration. There was also discussed development in Central Bohemian, in Ústí nad Labem, in Liberec and in the MoravianSilesian Regions. This group thus became a risk for accelerating inflation in the future period.

In 2014, RUWC indicator declined by even 2.2\%. Exceeding the growth of the gross added deflator above the level of the NUWC growth implied the absorption of wage and cost-related inflation pressures into the inflation of this period, as well as the non-existence of risk for accelerating the price level in the immediately following period. Manufacturers have reduced the growth of wage due to the need to cope with strong domestic and foreign competition. The reverse tendency was found only in the sectors of Information, Financial activities, and Real estate. In this group, an increase in the labour costs per unit of production reduced producers' profits.

\section{Quantification of the wage cost inflation potential of the Czech Republic in several perspectives}

The concurrence of creating the wage and cost related inflation potential on the mezzolevel with the whole national economy level was established already in 1996 (Table 1). The identical development with the national economy was followed in the sectors of Agriculture, Trade, Financial activities, Real estate, and in the sector of Other activities. In 2001 to 2005, the RUWC on the macro-level showed only a slight growth, a similar trend was found in nearly all sectors. In addition, the same trend was found in the overwhelming majority of regions. In 2008 and 2009, there was an annual RUWC growth on the national economy level in the amount of 1.5\%. The identical development was found in nearly all sectors. In 2011 and 2012, the average annual RUWC growth of $1.3 \%$ was supported practically by all sectors. In this respect, most regions may also be mentioned. 
Table 1 Overview of the period with wage cost inflation pressures at both the national economy and mezzo-level

\begin{tabular}{|c|c|c|c|}
\hline \multirow[b]{3}{*}{ Year } & \multirow{3}{*}{\begin{tabular}{|l} 
Macro-level \\
RUWC (y-to-y \\
changes in \%)
\end{tabular}} & \multicolumn{2}{|l|}{ Mezzo-level } \\
\hline & & Selected sectors & Selected regions \\
\hline & & $\begin{array}{l}\text { Number of } \\
\text { sectors }\end{array}$ & $\begin{array}{l}\text { Number of } \\
\text { regions }\end{array}$ \\
\hline 1996 & 2.9 & 7 & \\
\hline 1997 & 0.9 & 6 & 8 \\
\hline 1998 & -4.8 & 9 & 14 \\
\hline 1999 & -1.2 & 5 & 12 \\
\hline 2000 & -0.7 & 4 & 12 \\
\hline 2001 & 0.2 & 4 & 11 \\
\hline 2002 & 2.4 & 6 & 11 \\
\hline 2003 & 0.4 & 7 & 7 \\
\hline 2004 & 0.7 & 7 & 10 \\
\hline 2005 & 0.9 & 7 & 9 \\
\hline 2006 & -1 & 5 & 9 \\
\hline 2007 & -0.5 & 5 & 8 \\
\hline 2008 & 2.4 & 8 & 12 \\
\hline 2009 & 0.6 & 5 & 4 \\
\hline 2010 & -0.2 & 6 & 8 \\
\hline 2011 & 0.7 & 5 & 10 \\
\hline 2012 & 1.8 & 9 & 11 \\
\hline 2013 & -0.9 & 6 & 10 \\
\hline 2014 & -2.2 & 6 & \\
\hline
\end{tabular}

Source: Own calculation on the basis of data from the Czech Statistical Office.

The periods in which the RUWC did not grow in the whole national economy but only on the mezzo-level include the interval of 1998 to 2000. In particular, this included the sector of Agriculture, Industry, Trade, Financial activities, and Real estate. In addition, this applied to the regions of the Capital City of Prague and Karlovy Vary Region. Also in 2010, the RUWC indicator increased only on the mezzo-level in 4 sectors and 5 regions. In 2013, there was an RUWC growth only in the sectors of Agriculture, Information, Real estate, and Public Administration. In terms of regions, this applies to Central Bohemian, Ústí nad Labem, Liberec and MoravianSilesian Regions. In 2014, this applied only to the sectors of Information, Financial activities, Real state, and Other activities.

In addition, it is necessary to point out the doubts on the unambiguousness of creating extensive wage cost deflation potential in 2013 and 2014. While in 2013, the RUWC in the whole national economy saw an annual decline of $0.9 \%$ and in 2014 of even $2.2 \%$, four sectors demonstrated in both years a wage cost inflation potential. In 2013, the existence of this type of inflation potential was found in 4 regions.

In the context of the peaks and bottoms of the boom and recession, the analysis of the wage cost inflation potential shows that first recession bottom (the financial crisis in the Czech Republic in 1997) was accompanied on the macro-level with a moderate scope of the wage cost inflation potential. However, the sectors of Construction, Information, Public administration, and Other activities did not show the creation of the local wage cost inflation potential. A similar conclusion may also be made for the Liberec and Zlín Regions. The second recession bottom was localised in 2009, when the gross added value saw an annual decline and the RUWC on the macro-level grew only slightly. On the mezzo-level, no local inflation impulses 
arising from the salaries development were found in the sectors of Industry, Construction, Financial activities, Real estate, and Public administration. The same tendency was found in all the regions except the Capital City of Prague, Central Bohemian, Hradec Králové, and MoravianSilesian Regions. The third recession bottom was found in 2012, when the gross added value saw a slight decline. A contradictory trend with a high wage cost inflation potential on the national level was found only in the sector of Agriculture. In addition, the same applies to two regions (South Bohemian and Vysočina Regions).

The first boom peak was found in 2000 (with an annual growth of the gross added value). On the macro-level, all the wage cost inflation pressures were absorbed in the current inflation. However, the sectors of Trade, Information, Financial activities, Professional activities, Public administration demonstrated a local inflation potential. The same applied to the regions of the Capital City of Prague and Liberec Regions. The second boom peak was localised in 2006 (with an annual growth of the gross added value). On the macro-level, the RUWC dropped again but on the mezzo-level, local wage and cost relation inflation pressures were established (Agriculture, Construction, Financial activities, Real estate, and Public administration). The same situation occurred in 5 regions (Karlovy Vary, Vysočina, South Moravian, Olomouc, and Moravian-Silesian Regions). The last boom period was localised in 2014. On the level of the whole national economy, the RUWC even dropped by $2.2 \%$ but an opposite trend was found in 4 sectors (Information, Financial activities, Real estate, and Other Activities).

\section{Mapping the advance and delay in the development of the wage cost inflation potential on the mezzo-level compared to the macro-level}

On the level of the national economy, creating the wage cost inflation potential may also be examined in terms of its delay or advance compared to the development in some aspects of the examined mezzo-level. On the lower level, stopping the creation of the wage cost inflation potential $\left(^{*}\right)$ or the creation of the wage cost inflation potential $(\mathbf{x})$ thus becomes a leading indicator and a certain predictor of the development in the whole national economy in the nearest future. The symbols (\#) and (¥) then mean that material did not establish the creation of the wage cost inflation potential or that there was the creation of the wage cost inflation potential also in the period when a completely new tendency had been established on the level of the whole economy. 
Table 2 Overview of the period with advance ( ${ }^{*}$ and $\mathrm{x}$ ) / delay (\# and $¥$ ) in the development RUWC in sectors before development at the macro-level

\begin{tabular}{|c|c|c|c|c|c|c|c|c|c|c|c|}
\hline \multirow[b]{2}{*}{ Year } & \multirow{2}{*}{\begin{tabular}{|l|}
$\begin{array}{l}\text { Macro- } \\
\text { level }\end{array}$ \\
\\
RUWC \\
(y-to-y \\
changes \\
in \%)
\end{tabular}} & \multicolumn{10}{|c|}{ Mezzo-level } \\
\hline & & $\begin{array}{l}\text { Agricultu } \\
\text { re, } \\
\text { forestry } \\
\text { and } \\
\text { fishing }\end{array}$ & \begin{tabular}{|l} 
Manufact \\
uring, \\
mining \\
and \\
quarryin \\
g and \\
other \\
industry
\end{tabular} & $\begin{array}{l}\text { Constru } \\
\text { ction }\end{array}$ & \begin{tabular}{|l} 
Trade, \\
transport \\
ation, \\
accomm \\
odation \\
and food \\
service
\end{tabular} & $\begin{array}{l}\text { Informati } \\
\text { on and } \\
\text { commun } \\
\text { ication }\end{array}$ & $\begin{array}{l}\text { Financial } \\
\text { and } \\
\text { insuranc } \\
\text { e } \\
\text { activities }\end{array}$ & $\begin{array}{l}\text { Real } \\
\text { estate } \\
\text { activities }\end{array}$ & $\begin{array}{l}\text { Professi } \\
\text { onal, } \\
\text { scientific } \\
\text { technical } \\
\text { and } \\
\text { administ } \\
\text { rative } \\
\text { activities }\end{array}$ & $\begin{array}{l}\text { Public } \\
\text { administ } \\
\text { ration, } \\
\text { educatio } \\
\text { n, health } \\
\text { and } \\
\text { social } \\
\text { work }\end{array}$ & $\begin{array}{l}\text { Other } \\
\text { service } \\
\text { activities }\end{array}$ \\
\hline 1996 & 2.9 & + & + & * & + & * & + & + & - & + & + \\
\hline 1997 & 0.9 & + & + & * & + & * & + & + & + & * & * \\
\hline 1998 & -4.8 & - & - & - & - & - & - & - & $\neq$ & - & - \\
\hline 1999 & -1.2 & - & - & - & - & $\mathrm{x}$ & + & + & $\neq$ & + & - \\
\hline 2000 & -0.7 & - & - & - & $x$ & $x$ & + & - & $\neq$ & - & $x$ \\
\hline 2001 & 0.2 & \# & \# & \# & + & + & - & \# & - & + & + \\
\hline 2002 & 2.4 & + & + & $\#$ & + & - & + & + & - & - & + \\
\hline 2003 & 0.4 & + & + & \# & + & - & - & + & + & + & + \\
\hline 2004 & 0.7 & + & - & \# & + & + & - & + & + & + & + \\
\hline 2005 & 0.9 & - & + & \# & + & * & + & + & + & + & + \\
\hline 2006 & -1 & + & - & + & - & - & $\neq$ & $\neq$ & - & $\neq$ & - \\
\hline 2007 & -0.5 & - & $x$ & - & $x$ & $x$ & - & - & - & $\neq$ & $x$ \\
\hline 2008 & 2.4 & + & + & + & + & + & \# & + & + & + & + \\
\hline 2009 & 0.6 & + & * & * & + & + & \# & - & + & * & + \\
\hline 2010 & -0.2 & - & - & - & - & + & - & + & $\neq$ & - & + \\
\hline 2011 & 0.7 & $\#$ & + & + & + & - & + & - & - & + & - \\
\hline 2012 & 1.8 & \# & + & + & + & + & + & + & + & + & + \\
\hline 2013 & -0.9 & + & - & - & - & $\neq$ & - & $\neq$ & - & $\neq$ & - \\
\hline 2014 & -2.2 & - & - & - & - & $\neq$ & $x$ & $\neq$ & - & - & $x$ \\
\hline
\end{tabular}

Source: Own calculation on the basis of data from the Czech Statistical Office.

In the case of the sector analysis, the role of the leading indicator was played, in the examined period, by the sector of Information. In particular, in 1996 and 1997, for example, this sector did not demonstrate the accumulation of the wage cost inflation potential despite the contrary tendencies on the level of the whole economy. The sector of Other Activities also served as an equally good advance indicator. In 2014, this may even serve as a first indication of the approaching turn in the existing positive development of the assessment of the RUWC development on the macro-level. Another higher frequency of the established advanced in the positive development on the mezzo-level compared to the whole real economy was found in the sector of Construction (1996 to 1997 and 2009) and Public administration (1997 and 2009). The sector of Financial activities may be the predictor of negative changes in the development of the national economy in 2014 , when on average the economy still shows positive wage cost related signals.

It was further established that the sector of Real estate did not accumulate the wage cost inflation reserves also in 2001, when there were opposite tendencies on the level of the whole national economy. Repeatedly, a more intensive creation of the wage cost inflation potential on the mezzo-level was found, compared to the macroeconomics, in the sector of Professional activities (1998 to 2000 and 2010) and Public administration (2006 to 2007 and 2013). There was only one 
year in which we found a delay in stopping the creation of the wage cost inflation reserve in the sector of Industry (2001) for the whole economy. In Construction, this tendency lasted even until 2005. In the sector of Information, this also included extending the accumulation of the wage cost inflation reserve to 2012 and 2013, when on the level of the whole economy, the presence of the positive trend had already been confirmed.

In the examined period, the function of the leading indicator in terms of regions was played mainly by the Liberec Region (1997, 2005 and 2009). On the contrary, the regions which most often pointed out remaining in the existing development even though the development in the whole national economy had changed, included Central Bohemian, Moravian-Silesian and Ústí nad Labem Regions. The Liberec Region completed the group of regions (Central Bohemian, Ústí nad Labem and Moravian-Silesian Regions) which admitted that the positive tendencies in the development of the whole real economy in 2013 did not necessarily have to extend to the following years or several upcoming years.

\section{Conclusions}

The study revealed a wage cost inflation potential on the level of the whole Czech economy in 11 years in the average amount of $1.3 \%$. In the following 8 years, it is also possible to map local inflation sources on the mezzo-level. In particular, all 8 years showed the sectors with a negative wage cost inflation potential. In 6 years out of them, there were accumulated wage and cost related inflation pressures in several regions. In all these years, the growth of nominal and actual salaries was not followed by an adequate growth of the real quantities such as the growth in the labour productivity. The wage growth not corresponding to the development of the labour productivity became a risk for the macroeconomic stability, as the whole volume of the arising wage cost inflation pressures was not absorbed in the current price level (the deflator of the gross added value) and may thus be released in the following period. In the case of a stronger recovery, one may thus expect the growth of the manufacturers' pressures to reflect increase wage costs in the prices. In the case of local risks on the mezzo-level (in the established sectors or regions), there is also a risk of transferring the contamination in other economy sectors.

On the contrary, other chapters pointed out the positive signals concerning the wage intensity of the added value in the whole national economy of the Czech Republic. In particular, we found 8 years in which no wage cost inflation potential was localised on the macro-level of the Czech Republic. Partial positive signals may also be localised in the following 11 years. In all these years, we did not find any sectors with a wage cost inflation potential. In 10 years out of them, the lack of imbalances was found in several regions. The localised RUWC decline thus implies the absorption of the wage cost inflation pressures in the current inflation and the non-existence of risk for accelerating the price level in the upcoming future period, for instance due to an increase in the consumer demand or economic recovery. Reducing the labour costs per unit of the added value increased manufacturers' profits or helped them compensate rising costs. In addition, the absence of imbalance on the labour market was found in several sectors, regions and groups which reduce the risk of occurrence of wage cost inflation pressures for the future development of the whole economy owing to the transfer of good experience to other levels of the actual economy.

A higher annual growth of the deflator of the gross added value than the NUWC growth in 2013 (by $0.9 \%$ ) and in 2014 (by $2.2 \%$ ) implies the manufacturers' efforts to rationally control the wage intensity of the added value. It shows their effort to secure the advance of the dynamics of production indicators in relation to wage indicators, thus reducing the labour costs per unit of the 
added value. The resulting favourable development of the cost indicator on the labour market confirms the end of producing the wage related inflation potential. Furthermore, it implies that the actual development on the labour market should not, in the short-term, create risks for accelerating the growth of manufacturers' prices and subsequently consumer prices, for instance, in the context of increasing consumer demand or an economic recovery. Furthermore, the assessment of the mezzo-level in these last two years of the research indicates the doubts on the unambiguousness of the established existence of the wage cost related inflation potential on the macro-level. In fact, the development in 4 sectors was contrary to the positive development in the whole national economy. In 2013, the same applied to 4 regions, as well.

Mapping the recession points out the fact that on the macro-level, the wage cost inflation potential was found in all three periods. However, these years also saw a local wage cost non-inflation reserve in several sectors (Construction and Public Administration). Discontinuing the creation of the cost related inflation potential was also found in regions (Liberec, Zlín, South Bohemian, and Vysočina Regions). On the macro-level, no wage cost inflation potential was found in any of the three peaks of the boom period. Nevertheless, in this period, a local wage cost inflation potential was found in sectors (Financial activities, Information, Public Administration, Real estate, and Other activities). In the case of regions, the inflation source was localised in the Capital City of Prague, as well as in Liberec, Karlovy Vary, Vysočina, South Moravian, Olomouc, and MoravianSilesian Regions.

It also can be stated that in the case of the sectors, the role of the leading indicator of the development in the whole national economy in the upcoming future was played, in particular, by the sector of Information. In terms of the frequency of the revealed advanced in the local development ahead of the whole real economy was found in the sectors of Industry, Construction, Trade, and Public administration. In the examined period, in terms of regions, the role of the leading indicator was mainly played by the Liberec Region. It was followed by the Zlín Region with a positive outlook to the upcoming period. It was the South Bohemian Region that produced negative indications for the whole national economy.

Extending the length of the tendencies from the macro-level to another period on the local level was found mainly in the sector of Real estate. Compared to the macroeconomics, a repeatedly more intensive creation of the inflation reserve on the mezzo-level, was found in the sectors of Professional activities, Public administration, and Financial activities. The regions, that most frequently pointed out remaining in the existing development, included Central Bohemian, Moravian-Silesian, and Ústí nad Labem Regions.

The doubts on remaining in the development trend on the level of the whole economy in 2013 were not verified using the published 2014 macro-data for Central Bohemian, Ústí nad Labem, Liberec, and Moravian-Silesian Regions. In the case of the sectors of Other activities and Financial activities, the 2014 development may serve as a first indication to the approaching turn in the existing RUWC positive development on the macro-level.

\section{References}

CZECH NATIONAL BANK. (2014). III. Současný ekonomický vývoj. Zpráva o inflaci.

CZECH NATIONAL BANK. (2000b, Duben). 3. Trh práce. Materiál k projednání v bankovní radě Czech National Bank, 4. Situační zpráva o hospodářském a měnovém vývoji.

CZECH NATIONAL BANK. (2000, Březen). 3. Trh práce. Materiál k projednání v bankovní radě Czech National Bank, 3. Situační zpráva o hospodářském a měnovém vývoji. 
CZECH NATIONAL BANK. (2000, Únor). 3. Trh práce. Materiál k projednání v bankovní radě Czech National Bank, 2. Situační zpráva o hospodářském a měnovém vývoji.

CZECH NATIONAL BANK. (2000b, Leden). 3. Trh práce. Materiál k projednání v bankovní radě Czech National Bank, 1. Situační zpráva o hospodářském a měnovém vývoji.

CZECH NATIONAL BANK. (1999, Prosinec). 3. Trh práce. Materiál k projednání v bankovní radě Czech National Bank, 12. Situační zpráva o hospodářském a měnovém vývoji.

CZECH NATIONAL BANK. (1999, Listopad). 3. Trh práce. Materiál k projednání v bankovní radě Czech National Bank, 11. Situační zpráva o hospodářském a měnovém vývoji.

CZECH NATIONAL BANK. (1999b, Říjen 1999b). 3. Trh práce. Materiál k projednání v bankovní radě České národní banky, 10. Situační zpráva o hospodářském a měnovém vývoji.

CZECH NATIONAL BANK. (1999, Září 1999). 3. Trh práce. Materiál k projednání v bankovní radě Czech National Bank, 9. Situační zpráva o hospodářském a měnovém vývoji.

CZECH NATIONAL BANK. (1999, Srpen). 3. Trh práce. Materiál k projednání v bankovní radě Czech National Bank, 8. Situační zpráva o hospodářském a měnovém vývoji.

CZECH NATIONAL BANK. (1999b, Červenec). 3. Trh práce. Materiál k projednání v bankovní radě Czech National Bank, 7. Situační zpráva o hospodářském a měnovém vývoji.

CZECH NATIONAL BANK. (1999, Květen). 3. Trh práce. Materiál k projednání v bankovní radě Czech National Bank, 5. Situační zpráva o hospodářském a měnovém vývoji.

CZECH NATIONAL BANK. (1999b, Duben). 3. Trh práce, př́ijmy domácností. Materiál k projednání $v$ bankovní radě České národní banky, 4. Situační zpráva o hospodářském a měnovém vývoji.

CZECH NATIONAL BANK. (1999, Únor). 3. Trh práce. Materiál k projednání v bankovní radě Czech National Bank, 2. Situační zpráva o hospodářském a měnovém vývoji.

CZECH NATIONAL BANK. (2001b, Leden). Metodický rámec hodnocení mzdového vývoje ve vztahu $\mathrm{k}$ inflaci. Zpráva o inflaci.

CZECH NATIONAL BANK. (2001, Řijen). III. 4 Trh práce. Zpráva o inflaci.

CZECH NATIONAL BANK. (2001, Červenec). III. 3 Trh práce. Zpráva o inflaci.

CZECH NATIONAL BANK. (2001, Duben). III. 3 Trh práce. Zpráva o inflaci.

CZECH NATIONAL BANK. (2001a, Leden). III. 3 Trh práce. Zpráva o inflaci.

CZECH NATIONAL BANK. (2000, Říjen). III. 3 Trh práce. Zpráva o inflaci.

CZECH NATIONAL BANK. (2000, Červenec). III. 3 Trh práce. Zpráva o inflaci.

CZECH NATIONAL BANK. (2000a, Duben). III. 3 Trh práce. Zpráva o inflaci.

CZECH NATIONAL BANK. (2000a, Leden). III. 3 Trh práce. Zpráva o inflaci.

CZECH NATIONAL BANK. (1999a, Ríjen). III. 3 Trh práce. Zpráva o inflaci.

CZECH NATIONAL BANK. (1999a, Červenec). III. 3 Trh práce. Zpráva o inflaci.

CZECH NATIONAL BANK. (1999a, Duben). III. 3 Trh práce. Zpráva o inflaci.

CZECH NATIONAL BANK. (1999, Leden). III. 3 Trh práce, přijmy domácností. Zpráva o inflaci. 
CZECH NATIONAL BANK. (1998, Říjen). III. 3 Trh práce, príimy domácností. Zpráva o inflaci.

EUROPEAN COMMISSION. (2012). Alert Mechanism Report prepared in accordance with Articles 3 and 4 of the Regulation on the prevention and correction of macroeconomic imbalances. European Commission, COM (2012) 751 final.

LIPSKÁ, E., VLNKOVÁ, M. and MACKOVÁ, I. (2005). Jednotkové náklady práce. Na aktuálnu tému. Bratislava: Národná banka Slovenska.

PRUŠVIČ, D. and VLACH, J. (2006). Jednotkové náklady práce - analýza vývoje a úrovně. Research Institute of Labour and Social Affairs, Prague. ISBN 80-87007-11-5.

RAPUTA, T. $(2013,14.10$.). Kde hledat ten správný fundament? Analytical team FXstreet.cz, section of Fundamental Analysis.

RAPUTA, T. $(2013,28.1$.). Fundamentální analýza: Jednotkové náklady práce. Analytical team FXstreet.cz, section of Fundamental Analysis.

VLACH, J., KOZELSKÝ, T., BAŠTÝŘ, I., ŠLAPÁK, M., HÁLA, J. and PFEIFEROVÁ, Š. (2013). Sledování nákladů práce a práce jako výrobního faktoru $\vee$ ČR a v zahraničí. Research Institute of Labour and Social Affairs, Prague.

VLACH, J., and KOZELSKÝ, T. (2010). Konvergence ceny práce v ČR k evropským standardům a její využití v letech 2000-2008 (jednotkové náklady práce a podíl práce na nákladech).

\section{Web Links}

GDP, National Accounts - Quarterly national accounts - Gross domestic product - time series https://www.czso.cz/csu/czso/hdp cr

GDP, National Accounts - Annual national accounts - Regional accounts - Indicators in regional breakdown

http://apl.czso.cz/pll/rocenka/rocenka.indexnu reg 